\title{
HEALTH BEHAVIOR AND DENTAL CARRIES IN COASTAL COMMUNITY: LITERATURE REVIEW
}

\author{
Koko Komarudin*, Maharani Laillyza Apriasari**, Aulia Azizah*** \\ ${ }^{*}$ Doctoral Student of Social Science, Faculty of Social Science and Political Science, Universitas Airlangga \\ ${ }^{* *}$ Departement of Oral Medicine, Faculty of Dentistry, Universitas Lambung Mangkurat \\ ${ }^{* * * D e p a r t e m e n t ~ o f ~ D e n t a l ~ P u b l i c ~ H e a l t h, ~ F a c u l t y ~ o f ~ D e n t i s t r y, ~ U n i v e r s i t a s ~ L a m b u n g ~ M a n g k u r a t ~}$ \\ Correspondence: aulia.azizah@ulm.ac.id
}

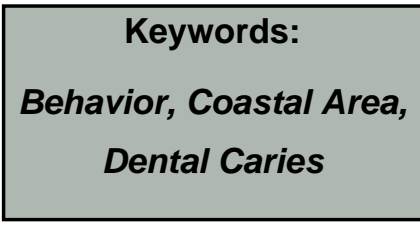

\begin{abstract}
Background: The important role of coastal communities is not directly in line with their living conditions, which are mostly poor. Dental caries is basically a disease that is also suffered by the general public in Indonesia, even in the world. RISKESDAS 2018 shows the prevalence of caries in Indonesia is $88.8 \%$. Dental caries is caused by the bacterium Streptococcus mutans. People who live in coastal areas are at risk of suffering from dental caries. Brushing behavior also has a relationship with the incidence of dental caries.
\end{abstract}

Method: All articles reviewed were obtained from Pubmed, Science Direct, and Google Scholar with a period of 10 years in full text. using the keywords behavior, caries, and coastal area.

Result: Based on reviews from several journals, it was found that the brushing behavior of coastal communities was good, but the frequency of brushing teeth was not appropriate and the behavior of using drinking water had no known fluoride content. There are variations in the category of dental caries at the age level of people in coastal areas.

Conclusion: Knowledge and healthy behavior can reduce the risk of dental caries related to the behavior of coastal communities, so that life productivity can be much better than ever.

\section{INTRODUCTION}

Coastal communities have a strategic role in strengthening Indonesia's attributes as a maritime country. The strategic roles carried out include supporting food security, especially the fish needs of the community, increasing state income from the fisheries sector and helping to uphold state sovereignty at sea. ${ }^{1,2,3}$ The important role played by coastal communities is in contrast to their living conditions. Poverty is still inherent in the lives of coastal communities, even they are categorized as the poorest of the poor people. The poor generally live in inadequate settlements, lack access to health services, poor nutrition, minimal health knowledge and lack of health behavior. These conditions make coastal communities vulnerable to disease. ${ }^{4,5}$

Some researches have been conducted on coastal community. Theses researches can at least be classified into three trends. The first type of studies examines the coastal community and poverty. $6,7,8$ This type of academic research on coastal community is more concerned on describing the factors that cause poverty and the forms of poverty as well as efforts to overcome poverty problem. The study has not examined poverty with vulnerability to disease. The second type focus on 
resilience coastal community.9,10 These authors strongly believe coastal community has capability to cope with obstacles internally as well as externally. Yet these study did not discuss specifically the abality coastal community in handling vulnerability to diseases. The third type of studies focusses on the character of the dental health in coastal communities that has been carried out by Sukmana (2016); Pranati, dkk (2019); and Lautetu, dkk (2019). This research focuses more on examining dental health in coastal areas which are still minimal and medical personnel are also still lacking so that they do not support and motivate the development of public health in a better direction. This research focuses more on examining dental health in coastal areas which are still minimal and medical personnel are also still lacking so that they do not support and motivate the development of public health in a better direction. ${ }^{11,12,13}$

A study that correlates coastal community behavior and dental caries as an essential complement to the previous reseaches on coastal community. People living in coastal areas, are not only low awareness and habits and behavior in maintaining dental and oral health, but also there are natural factors that cause caries in coastal communities. ${ }^{11,14}$ Caries is a disease of the hard tissues of the teeth, namely enamel, dentin and cementum due to the activity of a microorganism in a fermentable carbohydrate. The presence of demineralization of hard tooth tissue is a sign that then there is damage to organic material, so that as a result there will be bacterial invasion, pulp capacity and spread of infection to the periapical tissue which can cause pain. If the remineralization process occurs at a very early stage, caries can be stopped quickly. Caries disease in a person can be prevented by healthy living behavior. ${ }^{15}$

Dental caries is basically a public dental and oral health problem experienced by almost half of the world's population (3.35 billion people) based on The Global Burden Diseases Study in 2016. The results of the Basic Health Research (RISKESDAS) in 2018 show the prevalence of dental caries in Indonesia in amount of $88.8 \%$. The prevalence of dental caries tends to be high, above $70 \%$ in all age groups. The highest prevalence of dental caries was at the age of 55-64 years (96.8\%). ${ }^{16}$ Health problems are generally determined by two main factors, namely behavioral factors and nonbehavioral factors (environment and health services). ${ }^{17}$ This means that someone who does not behave in a healthy manner can experience health problems such as dental caries. Based on the description above, it is necessary to conduct a literature review study to describe the behavior and dental caries in communities in coastal areas.

\section{RESEARCH METHOD}

The data search in this study was conducted on the Pubmed, Science Direct and Google Scholar databases using the keywords behavior, dental caries, and coastal area. The sources reviewed are in Indonesian and English, published in 2011 up to 2021 in full text form. Literature review was synthesized using narrative method. Review analysis is carried out with problem formulation, searching for literature, evaluating data, analyzing, and interpreting.

\section{LITERATURE REVIEW}

\section{COASTAL AREA}

Based on Law no.1 of 2014 on the management of coastal areas and small islands, the coastal area is a transitional area between land and sea ecosystems that are affected by changes on land and sea. According to Dahuri, et al (2013), the coastal area is a transitional area between the 
ocean and land. Coastal areas have various uses such as residential areas, fisheries, agriculture, tourism, conservation as well as industrial areas. ${ }^{18}$

\section{BEHAVIOR}

Health behavior is a person's response to a stimulus or object related to illness and health, disease and influencing factors such as the environment, food, drink and health services. Health behavior is divided into two categories, namely: the behavior of healthy people to stay healthy and improve or called healthy behavior and the behavior of sick people or behaviors that are taken by someone when exposed to health problems to obtain healing or regardless of the health problems. ${ }^{17,19}$

Research by Pranati, et al (2019) in the coastal area of Kokilamedu, Chennai, Tamil Nadu, India showed that $93.85 \%$ brushed their teeth using a toothbrush and toothpaste but only $24.61 \%$ brushed their teeth more than once a day. The most consumed foods are meat and seafood (69\%) followed by vegetables and fruit at $20 \%$. Based on 65 respondents, those who were consumption of sweet foods was $64.61 \%$. The results showed that $96.92 \%$ had a smoking habit. $61.53 \%$ of the study respondents never visited the dentist. ${ }^{12}$

The behavior of brushing teeth was also shown in the study of Kumar, et al (2016), but only $25 \%$ of respondents used fluoride toothpaste. The greatest frequency is the same as the previous study, which is at least once a day. This study also shows that $88 \%$ of research respondents have never been to the dentist. The food consumed is fresh fruit and sweetened milk, and the consumption of sweet foods is more common in respondents in urban areas than in rural areas. ${ }^{20}$

The research of Suratri, et al (2018) shows that there is a significant relationship between the behavior of maintaining dental and oral hygiene with dental caries disease and the behavior of maintaining dental and oral hygiene. If people do not behave in maintaining dental and oral hygiene, there are 1.43 times the possibility of caries occurrence. The incidence of caries is related to tooth brushing behavior. The behavior of people in Indonesia in brushing teeth properly is only $2.8 \%$ according to RISKESDAS 2018. The occurrence of dental caries is not only associated with the time of brushing teeth but how to brush teeth correctly, and the frequency of brushing teeth. Caries in adults is also influenced by socio-economic conditions where it was found that people with lower socioeconomic status suffer from dental caries. Caries is also related to education and work as well as location of residence. 16,21,22

The behavior of coastal communities that can affect the incidence of caries is the behavior of daily drinking water consumption. One of the prevention factors for the occurrence of caries is the type of drinking water source consumed is a protected water source. Protected water facilities will be able to avoid the possibility of water being polluted, chemically or bacteriologically. The type of water source is closely related to the fluoride concentration in the water. The concentration of fluorine in groundwater and surface water usually exceeds the specified requirements. The concentration of fluorine in groundwater is usually higher than that in surface water. The fluoride content of rainwater is low below the specified conditions. Low fluoride content in water can cause dental caries, so fluoridation is necessary. Fluorine levels in refill drinking water, PAM water and bottled drinking water still meet the specified requirements on average below $1.5 \mathrm{mg} / \mathrm{mL}$. The research of Suratri, et al (2018) shows that almost all types of drinking water sources can cause dental caries except for drinking water from refilled water and tap water. ${ }^{14,22,23}$ 


\section{CARIES}

Caries disease often occurs in people in coastal areas. This is illustrated in Sukmana's research (2016), caries in coastal communities in Takisung Village, Takisung District, includes quite high criteria. The results showed that the distribution of decay categories was $57 \%$ with an average of 5.7 , missing $43 \%$ an average of 4.3 and filling 0 (zero). The results of the distribution of age groups are age $20-30$ years by $32 \%$ with the smallest DMF-T average of 2.1, age 31-40 years of $36 \%$ with an average DMF-T of 3.9 and age 41-50 years of $32 \%$ with the highest average DMF-T of 4.0. This shows that the people of Takisung Village have bad dental and oral health conditions. The results of Sukmana's research (2016) in accordance with the research of Bongo, et al (2020) show that dental caries is abundant in the northern coastal area of Norway in research respondents aged 18-75 years with DMF-T 6.6 including very high DMF-T category with health conditions teeth and mouth are in the bad category. ${ }^{11,24}$

Caries can also be experienced by children as shown by the research of Das, et al (2013) in the coastal areas of West Bengal India. The results showed that caries in permanent teeth in the age category $6-8$ years was $15.11 \%$ with $8.4 \%$ males (mean DMF-T 1.53) and $6.71 \%$ females (mean DMF-T 1.67). Caries in primary teeth aged 6-8 years was $58.99 \%$ with $30.22 \%$ male (average deft 3.85 ) and $28.77 \%$ female (mean deft 3.54 ). Caries in permanent teeth in the age category 9-11 years was $27.93 \%$ with $12.68 \%$ male (mean DMF-T 2.09 ) and $15.25 \%$ female (mean DMFT 1.76 ). The results of this study indicate that the prevalence of caries is lower than the study at the age of $>20$ years. ${ }^{25}$

Iswanto's research (2016) shows the distribution of DMF-T by age in the coastal area of Linuhu Village, East Likupang District, Bangka
Island. It has been conducted in the age categories of 13,14 and 15 years. The results showed that the age category of 13 years was $56.67 \%$ with a DMF$\mathrm{T}$ index of 2.34; 14 years old $23.33 \%$ with DMF-T index 3.28; age 15 years $20 \%$ with a DMF-T index of 2.00 . Category of male sex $36.67 \%$ with DMF-T index 2 ; The category of female sex is $63.33 \%$ with a DMF-T index of 2.78. Respondents with geographic location in coastal areas aged 13-15 years have a DMF-T index of 2.5 and are included in the low category. ${ }^{14}$

\section{DISCUSSION}

Dental caries or cavities are a public health problem in many countries around the world, but it is often underestimated. Caries is caused either by multiple factors or influenced by biological, behavioral and environmental factors. Residents who are geographically located in different locations have different caries risks. Dental caries is a disease that can be prevented if the causes are known and prevention is carried out immediately, so early diagnosis is important. ${ }^{14,20,21}$

Dental caries is an infectious disease caused by demineralization of enamel and dentin. Caries occurs in teeth due to the role of cariescausing bacteria, namely those found in the Streptococcus mutans group in the mouth called Streptococcus mutans. Indonesia continues to face serious challenges related to dental and oral health status in children continuing into adolescence and adulthood, where $70 \%$ of them have had experiences related to caries. ${ }^{15,16,20}$

The causes of low oral hygiene, high decay and the number of missing teeth are caused by people not paying attention to the condition of their teeth and mouth. Dental caries can be prevented by brushing teeth regularly at least twice a day, i.e. after every meal and going to bed at night by using an appropriate toothbrush and fluoridated 
toothpaste. The habit of brushing teeth can also affect the severity of caries. The results of the study on correspondents who brush their teeth have a tendency to have milder caries than those who do not brush their teeth. ${ }^{21,23,25}$

There are differences in the average DMF$T$ value which is influenced by several factors that can cause dental caries, for example food consumption factors. Coastal communities in general have a habit of consuming seafood every day, hence there are differences in food consumption patterns in an area influenced by the presence or absence of food supplies. The need for availability of food sources depends on factors such as infrastructure, geographical location, water resources, type of work, transportation and climate. Communities in coastal areas usually have a high frequency of consuming fish because in coastal areas the average population has a job as a fisherman. Coastal communities can consume catches from the sea. Seafood contains more minerals than other foods. The fluoride content in seafood such as fish can reach 1.0 ppm. ${ }^{11,23,24,26}$

The body needs fluoride for metabolic processes. Fluoride levels that are too high can cause bone loss, stomach disease, and brown tooth enamel if the fluoride level is more than $2.5 \mathrm{mg} / \mathrm{l}$. Teeth become brittle, tooth decay, susceptible to dental caries, discoloration of children's teeth, and bone thinning can occur if there is a lack of fluoride. This shows that there is a relationship between fish consumption patterns with the incidence of dental caries and periodontal disease with high fish consumption patterns. ${ }^{26}$

The incidence of dental caries is also related to the fluoride content in drinking water. Physical, chemical, bacteriological, and radioactive requirements must be met for clean water standards that can be used by the community. One of the chemicals found in water is fluorine. The concentration of fluorine in water is closely related to the type of water source. Fluorine concentrations in surface water and groundwater generally exceed the specified requirements. If there is no treatment (defluoridation), high levels of fluoride in water can harm dental health. On the other hand, low fluoride content in water can also cause dental caries, so fluoridation is necessary. Dental and oral health status is closely related to the behavior or habits of the community in maintaining dental and oral health and also the condition of their drinking water. ${ }^{27,28,29}$ Oral health is very essential to keep in mind, since any problems in the oral cavity will affect a person's health holistically. This will reduce a person's productivity to carry out daily activities.

Evaluation of the influence of different environments on oral and dental health is a significant area of public health research. It is important to look at risk factors for dental and oral health behavior so that they can be modified in planning health promotion activities. It is very important for people living in coastal areas to behave in a healthy way and local institutions need to pay attention to healthy living.

\section{CONCLUSION}

Knowledge and healthy behavior can reduce the risk of dental caries related to the behavior of coastal communities, so they can increase their life productivity

\section{REFERENCES}

1. Andriati R. Antropologi Maritim. Surabaya: PT Revka Petra Media; 2012.

2. Anwar Z, Wahyuni. Miskin Di Laut Yang Kaya: Nelayan Indonesia Dan Kemiskinan. Sosioreligius, 2019;1(4):52-60.

3. Nasution AM. Peran Nelayan Dalam Membantu Instansi Penegak Hukum Laut Untuk Mencegah Ancaman Keamanan 
Maritim. Jurnal Pertahanan \& Bela Negara, 2018;8(1):85-104.

https://doi.org/10.33172/jpbh.v8i1.267

4. Chen Q., Su H., Yu X., Hu Q. Livelihood vulnerability of marine fishermen to multistresses under the vessel buyback and fishermen transfer programs in China: The case of Zhoushan City, Zhejiang Province. Int. J. Environ. Res. Public Health,. 2020;17(3):117. https://doi.org/10.3390/ijerph17030765

5. Sudjadi A., Widanti A., Sarwo B., Sobandy H. Penerapan Kesehatan Masyarakat Miskin Yang Ideal Dalam Pelayanan Kesehatan Masyarakat Miskin Melalui Program Jamkesmas. SOEPRA Jurnal Hukum Kesehatan, 2017;3(1):15-25.

6. Jamilah dan Mawardati. Hubungan Kemiskinan dan Pemanfaatan Sumber Daya Perikanan Tangkap Pada Kawasan Minapolitan. Jurnal Ekonomi Pertanian dan Agribisnis (JEPA), 2019;3(2):336-347.

7. Tain A. Penyebab Kemiskinan Rumah Tangga Nelayan di Wilayah Tangkap Lebih Jawa Timur. HUMANITY, 2011;7(1):01-10.

8. Goso, Anwar SM. Kemiskinan Nelayan Tradisional Serta Dampaknya Terhadap Perkembangan Kumuh. Jurnal Managemen, 2017;3(1):25-36.

9. Gai AM., Soewarni I., Sir MM. The concept of community poverty reduction in coastal area of Surabaya based on sustainable livelihood approach. IOP Conf. Ser.: Earth Environ. Sci., 2018; $\quad 137: 1-10 . \quad$ doi:10.1088/17551315/137/1/012099

10. Hasibuan F., Widiono S., Badrudin R. Resiliensi Struktur Keluarga Nelayan: Studi Kasus Respon Keluarga Nelayan Terhadap Dampak Perubahan Iklim di Pantai Pasar Bawah Bengkulu Selatan. AGRISEP, 2017;16(2): 201-210.

11. Sukmana B.I. Gambaran Karies Dengan Menggunakan DMF-T pada Masyarakat Pesisir Pantai Kelurahan Takisung Kecamatan Takisung Kabupaten Tanah Laut. Dentino Jur. Ked. Gigi, 2016;1(2): 182-185.

12. Pranati T, Ganapathy MD., Bennis MA., Kumar RP. Caries status among fishing community in Chennai - A survey. Drug Invention Today, 2019;12:545-549.

13. Lautetu LM., Kumurur VA., Warouw F. Karakteristik Pemukiman Masyarakat pada Kawasan Pesisir kecamatan Bunaken. Jurnal Spasial, 2019;6:126-136.

14. Iswanto L., Posangi J., Mintjelungan CN. Profil status karies pada anak usia 13-15 tahun dan kadar fluor air sumur di daerah pesisir pantai dan daerah pegunungan. Jurnal e-GiGi (eG), 2016;4(2):115-123.

15. Kidd EAM, Joyston-Bechal S. Essentials of Dental Caries, terj. Narlan Sumawinata dan Safrida Faruk. Jakarta, ECG; 2013:1-4.

16. Kemenkes RI. Laporan Hasil Kesehatan Dasar tahun 2018. Jakarta: Badan Penelitian dan Pengembangan Kesehatan Departemen Kesehatan RI, 2018;181-222.

17. McKenzie JF., Pinger RR., Kotecki JE. An Introduction to Community Health $4^{\text {th }}$ ed. Kesehatan Masyarakat Suatu Pengantar Edisi 4. Jakarta, EGC;2014:5-9.

18. Dahuri R., Rais J., Ginting Putra S., Sitepu M.J. Pengelolaan Sumber Daya Pesisir Secara Terpadu. Jakarta: PT. Balai Pustaka (Persero), 2013.

19. Notoatmodjo S. Promosi Kesehatan Teori dan Aplikasi. Jakarta, Rineka Cipta; 2018:43-80.

20. Santhosh K., Jyothi T., Prabu D., Kulkarni. Dental Caries and its Socio-Behavioral Predictors: An Exploratory Cross-Sectional Study. The Journal of Clinical Pediatric Dentistry, 2016;40(3):186-192.

21. Suratri MAL., Tjahja I., Setiawaty V. Correlation between dental health maintenance behavior with Dental Caries Status (DMF-T). Bali Med J, 2018;7(1):56-60.

22. Suratri MAL., Jovina TA., Notohartojo IT. Hubungan Kejadian Karies Gigi dengan Konsumsi Air Minum pada Masyarakat di Indonesia. Media Litbangkes. 2018;28(3): 211218.

23. Nayoan GSJ., Pangemanan DHC., Mintjelungan CN. Status Kebersihan Gigi dan Mulut pada Nelayan di Kelurahan Bahu Kecamatan Malalayang Kota Manado Sulawesi Utara. Jurnal e-GiGi (eG), 2015;3(2):495-501.

24. Bongo A-KS, Brustad M, Jönsson B. Caries experience among adults in core Sámi areas of Northern Norway. Community Dent Oral Epidemiol.2020;00:1-9. https://doi.org/10.1111/cdoe.12613

25. Das D., Misra J., Mitra M., Bhattacharya B., Bagchi A. Prevalence of dental caries and treatment needs in children in coastal areas of West Bengal. Contemp Clin Dent 2013;4:482487.

26. Noviasari AN., Christiono S., Hadianto E. Perbedaan Kekerasan Permukaan Enamel Gigi Desidui Terhadap Pola Konsumsi Ikan 
Laut. Dental Journal Odonto, 2018;5(1):76-79.

27. Sumiok JB., Pangemanan DHC., Niwayan M. Gambaran Kadar Fluor Air Sumur Dengan Karies Gigi Anak Di Desa Boyongpante Dua. Jurnal Ilmiah Farmasi Pharmacon, 2015;4(4):2302-2493.

28. Sminingrat A., Wahluyo S., Saskianti. The fluoride and calcium effect of drink water on dental caries prevalence in children of 6-8 years old (Observational research in Bangkalan regency). Eurasia J Biosci, 2020;14:3683-3687.

29. Yani RWE., Palupi R., Bramantoro T., Setijanto D. Analysis of Calcium Levels in Groundwater and Dental Caries in the Coastal Population of an Archipelago Country. Journal of Medical Science, 2019; 7(1):134-138. 